\title{
Equilibrium
}

Quarterly Journal of Economics and Economic Policy

VOLUME 9 ISSUE 1, 2014

p-ISSN 1689-765X, e-ISSN 2353-3293

www.economic-policy.pl

Ptak M. (2014), Norwegian Tax System from the Point of View of Climate Change Policy, "Equilibrium. Quarterly Journal of Economics and Economic Policy", Volume 9, Issue 1, pp. 71-89, DOI: http://dx.doi.org/10.12775/EQUIL.2014.005

\section{Norwegian Tax System from the Point of View of Climate Change Policy}

\section{JEL Classification: $A 11, A 12$}

Keywords: climate change policy, taxes, Norway

\begin{abstract}
Norway was the first country in the world to fix a carbon dioxide target. Norway was also one of the first countries to implement taxes to increase incentives to reduce greenhouse gas emissions. The aim of the paper is to analyse the role of environmental taxes in Norwegian climate policy. The author also examines the differences between the climate change policy measures in Norway and in the European Union countries, especially Poland.The first part of the paper contains an analysis of data on greenhouse gas emissions in Norway in the years 1990-2011. In the further sections of the paper the discussion is focused on the characteristics of Norwegian tax system and design of taxes used in Norway as instruments for addressing climate change. Particular attention is paid to the carbon tax, in force since 1991. The tax is responsible for large $\mathrm{CO}_{2}$ emission reductions. The paper is largely based on review of various reports, literature and websites on climate change policy, energy policy and transport policy in Norway.
\end{abstract}

(C) Copyright Institute of Economic Research \& Polish Economic Society Branch in Torun Date of submission: April 12, 2013; date of acceptance: November 7, 2013

*Contact: michal.ptak@ue.wroc.pl, Uniwersytet Ekonomiczny we Wrocławiu, Wydział Ekonomii, Zarządzania i Turystyki, ul. Nowowiejska 3, 58-500 Jelenia Góra, Poland 


\section{Introduction}

Climate change is one of the most important global environmental problems. The greenhouse effect that is leading to climate change is caused by a group of gases in the atmosphere which are transparent to incoming solar radiation, but trap infrared radiation (Czaja, Becla 2002, pp. 210-212). Greenhouse gases include, among others, carbon dioxide, methane, nitrous oxide, hydrofluorocarbons (HFCs), perfluorocarbons (PFCs) and sulphur hexafluoride.

The reduction of the greenhouse gas emissions caused by human action is the objective of climate change policy. Greenhouse gas emissions can be reduced by inter alia: employing alternative low-carbon fuels, increasing energy efficiency or using energy-saving technologies.

Policy instruments to address greenhouse gas emissions may include various instruments, such as regulatory instruments (such as fuel standards or energy standards for buildings), economic or market instruments (such as emission trading schemes or environmental taxes) and other instruments, for example voluntary agreements between industry and government.

Taxes, when appropriately designed, may be not only environmentally effective, but also cost-effective climate policy tools. This is because tax payers set their emission levels to the one where marginal abatement costs equal the tax rate. Equalisation of marginal abatement cost across firms is a condition for cost-effectiveness. It should be noted that taxes could be levied not only on greenhouse gas emissions, but also on energy products or vehicles.

Norway has great experience in implementing climate policy. As early as in 1989 Norway set a $\mathrm{CO}_{2}$ target of stabilization of emissions until 2000. Norway became the first country in the world to declare such target (Andersen et al. 2000, p. 46). The main policy instruments in Norway's climate policy are, in addition to tradable emission allowances, environmental taxes (The National Budget 2012).

The aim of this paper is to analyze the role of taxes in the Norwegian climate policy. Special attention is devoted to the structure of taxes which may promote various activities aimed at reducing emissions of gases responsible for climate change. The study also includes some comparison of measures to fight climate change in Norway with the measures used in Poland and in other European Union member states. 


\section{Methodology of the research}

The paper is largely based on review of various reports, literature and websites on climate change policy, energy policy and transport policy in Norway. The reports are published by the Norwegian Ministry of the Environment, Nordic Council of Ministers, Statistics Norway or Organisation for Economic Co-operation and Development.

The paper also reviews literature and reports on taxation, environmental policy and energy.

The paper focuses on the period 1990-2012.

\section{Greenhouse gas emissions in Norway}

Under the Kyoto Protocol, Norway committed to ensuring that its greenhouse gas emissions do not exceed 1990 levels by more than $1 \%$ during 2008-2012. As shown in Table 1, between 1990 and 2011 greenhouse gas emissions in Norway grew by $5,8 \%{ }^{1}$.

Table 1. Greenhouse gas emissions from Norwegian territory by sector in the years 1990-2011, million tonnes of carbon dioxide equivalent

\begin{tabular}{|l|r|r|r|r|}
\hline \multicolumn{1}{|c|}{ Specification } & \multicolumn{1}{c|}{$\mathbf{1 9 9 0}$} & \multicolumn{1}{c|}{$\mathbf{2 0 0 0}$} & \multicolumn{1}{c|}{$\mathbf{2 0 1 0}$} & \multicolumn{1}{c|}{$\mathbf{2 0 1 1}$} \\
\hline Total & 49,8 & 53,4 & 53,9 & 52,7 \\
\hline Oil and gas extraction & 7,7 & 12,6 & 13,8 & 13,4 \\
\hline $\begin{array}{l}\text { Manufacturing industries and } \\
\text { mining }\end{array}$ & 19,1 & 17,0 & 12,1 & 11,9 \\
\hline Energy supply & 0,3 & 0,5 & 2,3 & 2,1 \\
\hline $\begin{array}{l}\text { Heating in other industries and } \\
\text { households }\end{array}$ & 2,6 & 1,8 & 1,9 & 1,4 \\
\hline Road traffic, of which: & 7,8 & 8,5 & 10,1 & 10,1 \\
\hline \multicolumn{1}{|c|}{ passenger cars } &. &. & 5,6 &. \\
\hline $\begin{array}{l}\text { Aviation, navigation, fishing, } \\
\text { motor equipment }\end{array}$ & 5,6 & 6,3 & 7,2 & 7,2 \\
\hline Agriculture & 4,5 & 4,5 & 4,3 & 4,2 \\
\hline Other sources & 2,1 & 2,1 & 2,3 & 2,4 \\
\hline
\end{tabular}

Source: Guide to environment statistics (2012, p. 19), Statistical yearbook of Norway 2012 (2012, p. 58).

\footnotetext{
${ }^{1}$ Only emissions covered under the Kyoto Protocol. The figures do not include greenhouse gas emissions from international aviation and maritime transport. In 2009 the emissions from these sectors were 11,9 million tonnes of carbon dioxide equivalent.
} 
The main sources of greenhouse gas emissions are the oil and gas extraction sector, manufacturing industries and mining and road traffic. The largest contributor to the Norwegian greenhouse gas emissions is carbon dioxide. Between 1990 and 2011 its share increased from 69\% to 84\% (Emissions of greenhouse gases).

Figure 1 provides information on carbon dioxide emissions per capita in Norway and in European Union member states.

Figure 1. Carbon dioxide emissions per capita in Norway and in European Union member states in 2009 (tonnes per capita)

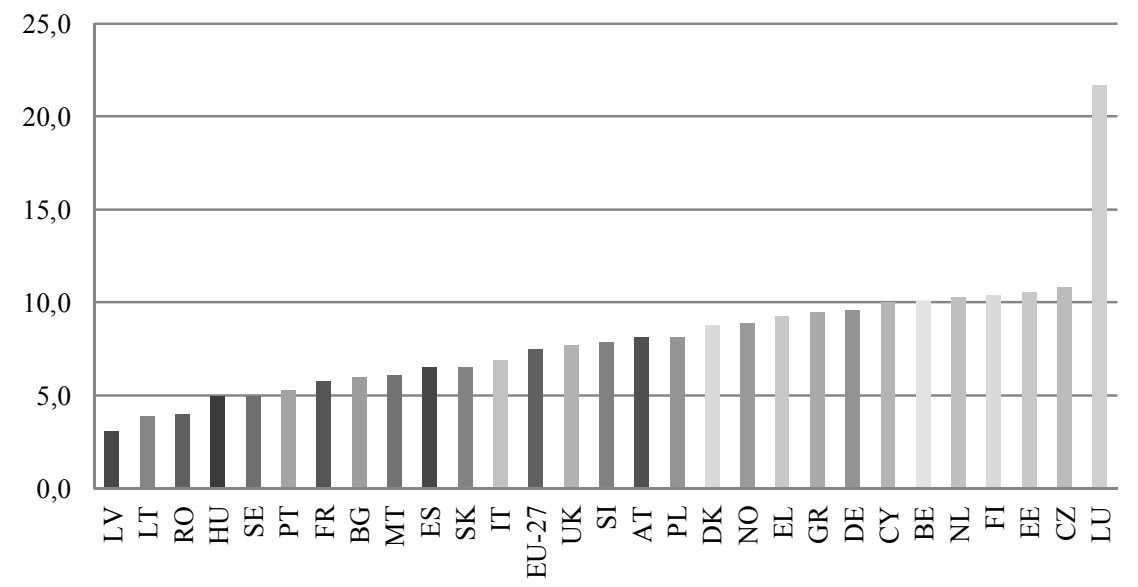

Source: Eurostat data.

Figure 1 shows that the $\mathrm{CO}_{2}$ emissions per capita in Norway are slightly higher than the emissions per inhabitant in Poland and the average emissions per capita in the EU. Relatively high $\mathrm{CO}_{2}$ emissions per capita in Norway compared with other European countries are due to high energy use in Norway. The high energy use is the result of the structure of the Norwegian economy, intemperate climate and low density of population (OECD 2011, p. 120).

It is worth noting that the 1989 climate change policy target was rejected in 1995. The Norwegian government considered the reduction target too difficult to achieve. There is currently a focus on a new target of $30 \%$ reduction of emissions by 2020, compared to 1990 (Norway's fifth national... 2010). This goal is very ambitious and goes further than the EU's goal of $20 \%$ reduction by 2020 (OECD 2011, p. 28). 


\section{The characteristics of the Norwegian tax system and its role in environmental policy}

Norwegian tax system as tax systems in other OECD countries is mainly based on income taxes (personal income taxes and corporate income taxes) and on consumption taxes, for example excise taxes (OECD 2012, p. 69). The Eurostat harmonized methodology allows one to compare the structure of tax revenues in Norway and in European Union member states (Table 2).

Table 2. Selected indicators of tax systems in the 27 European Union countries, Norway and Poland in 2010

\begin{tabular}{|l|c|c|c|c|}
\hline \multirow{2}{*}{ Specification } & $\begin{array}{c}\text { Personal } \\
\text { income } \\
\text { taxes }\end{array}$ & $\begin{array}{c}\text { Corporate } \\
\text { income } \\
\text { taxes }\end{array}$ & \multicolumn{2}{c|}{$\begin{array}{c}\text { Excise duties and other } \\
\text { consumption taxes }\end{array}$} \\
\cline { 2 - 5 } & \multicolumn{3}{|c|}{ as \% of GDP } & $\begin{array}{c}\text { as \% of total } \\
\text { taxation }\end{array}$ \\
\hline $\begin{array}{l}\text { EU-27 (arithmetic } \\
\text { average) }\end{array}$ & 7,7 & 2,7 & 3,2 & 9,3 \\
\hline $\begin{array}{l}\text { EU-27 (GDP- } \\
\text { weighted average) }\end{array}$ & 9,1 & 2,4 & 2,7 & 6,9 \\
\hline Norway & 10,1 & 10,1 & 2,2 & 5,1 \\
\hline Poland & 4,5 & 2,0 & 4,2 & 13,2 \\
\hline
\end{tabular}

Source: Taxation trends in the European Union (2012, pp.188-189, 196, 198).

Table 2 shows that in Norway the share of income taxes in GDP is relatively high. It is worth noting that the income taxation as a share of GDP in Norway is one of the highest among OECD countries (OECD 2012, p. 69). Corporate income taxes also generate relatively large revenues, mainly thanks to tax payments by petroleum sector. The petroleum companies are subject to an increased tax rate of $50 \%$ (the standard corporate tax rate is $28 \%$ ). Hydropower plants are also subject to an increased corporate income tax rate (of 30\%) (OECD 2012, p. 69). 
Another observation from Table 2 is that the share of excise duties in tax revenues in Norway is much lower than in Poland ${ }^{2}$.

Table 3 presents Eurostat data about the ratio of environmental taxes to total tax revenues in Norway, 27 European Union countries and Poland. The data shows that ,green” taxes (especially energy taxes) in Norway raise relatively low revenues. On the other hand, transport taxes in Norway generate relatively more revenues than taxes levied on means of transport in the European Union countries and in Poland.

Table 3. The share (in \%) of environmental taxes in total tax revenues in the European Union, Norway and Poland in the years 2000-2010

\begin{tabular}{|l|c|c|c|c|c|c|c|c|c|c|c|}
\hline \multirow{2}{*}{$\begin{array}{c}\text { Environmental } \\
\text { taxes }\end{array}$} & $\mathbf{2 0 0 0}$ & $\mathbf{2 0 0 5}$ & $\mathbf{2 0 1 0}$ & $\mathbf{2 0 0 0}$ & $\mathbf{2 0 0 5}$ & $\mathbf{2 0 1 0}$ & $\mathbf{2 0 0 0}$ & $\mathbf{2 0 0 5}$ & $\mathbf{2 0 1 0}$ \\
\cline { 2 - 10 } & \multicolumn{3}{|c|}{$\mathbf{E U}^{\text {a) }}$} & \multicolumn{4}{|c|}{ Norway } & \multicolumn{3}{c|}{ Poland } \\
\hline $\begin{array}{l}\text { Total environ- } \\
\text { mental taxes }\end{array}$ & 7,6 & 7,7 & 7,4 & 7,0 & 6,5 & 6,1 & 6,4 & 8,1 & 8,1 \\
\hline Energy taxes & 5,4 & 5,5 & 5,6 & 3,6 & 2,8 & 2,8 & 5,4 & 6,9 & 6,7 \\
\hline $\begin{array}{l}\text { Transport fuel } \\
\text { taxes }\end{array}$ & $\cdot$ & 4,6 & 4,7 & $\cdot$ & 2,0 & 1,8 & $\cdot$ & 5,5 & 5,9 \\
\hline $\begin{array}{l}\text { Other transport } \\
\text { taxes }\end{array}$ & 2,0 & 1,8 & 1,5 & 2,9 & 3,3 & 2,9 & 0,6 & 0,9 & 0,7 \\
\hline $\begin{array}{l}\text { Taxes on pollu- } \\
\text { tion or re- } \\
\text { sources }\end{array}$ & 0,3 & 0,3 & 0,3 & 0,5 & 0,4 & 0,4 & 0,5 & 0,3 & 0,7 \\
\hline
\end{tabular}

a) Arithmetic average. b) Value added taxes and taxes on oil extraction are not classified as environmental taxes in the Eurostat methodology.

Source: Taxation trends in the European Union. 2012 edition (2012, pp. 246-247, 249, 251, 253, 255).

Environmental taxes in Norway are levied on fuels, lubricants, motor vehicles, waste disposed at landfills or waste delivered for incineration, emissions of nitrogen oxides, beverage containers, pesticides, chemical compounds such as tetrachloroethylene or trichloroethylene. The Table 4 shows tax revenues from the taxes which may promote the reduction of greenhouse gas emissions in Norway.

\footnotetext{
${ }^{2}$ Some authors consider the high ratio of excise duties to tax revenues as an advantage of the tax system in Poland (Samojlik 2006, p. 71).
} 
Table 4. Revenue from selected taxes in Norway in the years 2006-2011

\begin{tabular}{|c|c|c|c|c|c|c|}
\hline Taxes & 2006 & 2007 & 2008 & 2009 & 2010 & 2011 \\
\hline \multicolumn{7}{|c|}{ NOK billion } \\
\hline Total tax revenues & 608,05 & 638,71 & 719,64 & 634,83 & 650,34 & 746,25 \\
\hline Tax on mineral oils & 0,79 & 0,74 & 1,33 & 1,32 & 1,48 & 1,53 \\
\hline Electricity consumption tax & 6,11 & 5,99 & 6,32 & 6,79 & 7,32 & 7,34 \\
\hline Petrol tax & 8,48 & 8,16 & 7,86 & 7,70 & 7,39 & 6,94 \\
\hline Autodiesel tax & 5,73 & 6,38 & 7,22 & 7,77 & 8,53 & 9,18 \\
\hline $\begin{array}{l}\text { Environmental tax on min- } \\
\text { eral products (carbon tax) }\end{array}$ & 4,49 & 4,56 & 4,54 & 4,50 & 4,66 & 4,85 \\
\hline $\begin{array}{l}\mathrm{CO}_{2} \text { tax on extraction of } \\
\text { petroleum }\end{array}$ & 3,41 & 3,39 & 3,39 & 2,22 & 2,17 & 2,19 \\
\hline Sales tax on motor vehicles & 19,68 & 21,69 & 18,94 & 15,88 & 19,72 & 20,12 \\
\hline Tax on greenhouse gases & 0,18 & 0,22 & 0,25 & 0,24 & 0,26 & 0,26 \\
\hline $\begin{array}{l}\text { Excise on final treatment of } \\
\text { waste }\end{array}$ & 0,60 & 0,68 & 0,70 & 0,49 & 0,28 & 0,09 \\
\hline \multicolumn{7}{|c|}{ Percent of total tax revenue } \\
\hline Tax on mineral oils & 0,13 & 0,12 & 0,18 & 0,21 & 0,23 & 0,21 \\
\hline Electricity consumption tax & 1,01 & 0,94 & 0,88 & 1,07 & 1,13 & 0,98 \\
\hline Petrol tax & 1,39 & 1,28 & 1,09 & 1,21 & 1,14 & 0,93 \\
\hline Autoc & 0,94 & 1,00 & 1,00 & 1,22 & 1,31 & 1,23 \\
\hline $\begin{array}{l}\text { Environmental tax on min- } \\
\text { eral products (carbon tax) }\end{array}$ & 0,74 & 0,71 & 0,63 & 0,71 & 0,72 & 0,65 \\
\hline $\begin{array}{l}\mathrm{CO}_{2} \text { tax on extraction of } \\
\text { petroleum }\end{array}$ & 0,56 & 0,53 & 0,47 & 0,35 & 0,33 & 0,29 \\
\hline Sales tax on motor vehicles & 3,24 & 3,40 & 2,63 & 2,50 & 3,03 & 2,70 \\
\hline Tax on greenhouse gases & 0,03 & 0,03 & 0,03 & 0,04 & 0,04 & 0,03 \\
\hline $\begin{array}{l}\text { Excise on final treatment of } \\
\text { waste }\end{array}$ & 0,10 & 0,11 & 0,10 & 0,08 & 0,04 & 0,01 \\
\hline
\end{tabular}

Source: Statistical yearbook of Norway 2010 (2010, p. 382), Statistical yearbook of Norway 2012 (2012, p. 384).

Table 4 confirms that the taxes on energy are of relatively low economic importance in Norway. However, it should be noted that the structure of tax revenue in Norway is very specific, since approximately one third of this revenue comes from taxes levied on petroleum sector (mainly from income taxes, but also from other taxes, such as taxes on oil extraction, carbon dioxide or nitrogen oxides emissions). The tax which generates significant revenue is, as in other counties, the value added tax. The share of VAT in total tax revenue in Norway in 2011 was around $28 \%$. 
To assess the relative importance of environmentally related tax revenues in a given country one can use a measure called implicit tax rate (ITR). In the case of energy taxation the implicit tax rate (ITR on energy) is calculated as the ratio between total energy tax revenues and final energy consumption (Taxation trends in ... 2010, p. 22). As Table 5 shows, the level of this indicator in 2009 in Norway was nearly 183 euro per tonne of oil equivalent. The indicator level was much higher than in Poland and other Central and Eastern European countries. On the other hand, the tax burden on energy in Norway is significantly lower than in a number of the EU countries, such as the Netherlands, Italy and Denmark, where the ITR on energy exceeds 230 euro/toe.

Table 5. ITR on energy in Norway, European Union and Poland in the years 19952009 (euro per tonne of oil equivalent)

\begin{tabular}{|l|r|r|r|c|}
\hline \multicolumn{1}{|c|}{ Specification } & $\mathbf{1 9 9 5}$ & $\mathbf{2 0 0 0}$ & $\mathbf{2 0 0 5}$ & $\mathbf{2 0 0 9}$ \\
\hline EU-27 (arithmetic average) & 96,1 & 122,0 & 143,7 & 166,5 \\
\hline EU-27 (GDP-weighted average) & 156,9 & 187,0 & 189,8 & 198,5 \\
\hline Norway & 131,4 & 155,3 & 161,0 & 182,9 \\
\hline Poland & 20,9 & 58,7 & 95,3 & 106,8 \\
\hline
\end{tabular}

Source: Taxation trends in the European Union. 2012 edition (2012).

It is worth noting that there are no earmarked taxes for environmental protection purposes in Norway (Hass, Sørensen, Erlandsen, Smith, 2002, p. 40). Such taxes or charges are applied in some European Union countries, especially in Central and Eastern Europe, including Poland.

\section{Taxes with implications}

\section{for greenhouse gas emissions}

As mentioned, in Norway there are several taxes which can contribute to achieving the objectives of climate policy. The most important is the carbon tax, which was implemented already in 1991. The main purpose of the carbon tax was to reduce carbon dioxide emissions. The tax was considered as a cost-effective approach to achieving environmental objectives.

Generally, carbon taxes can be levied on carbon dioxide emissions or on carbon content of fuel (as $\mathrm{CO}_{2}$ emissions depend on the carbon content of the fuel). In Norway the carbon tax is levied both on energy carriers (except electricity) and on emissions from platforms, installations or facilities for the extraction and transportation of petroleum on continental shelf (Taxation 
$o f . . .2007)$. The carbon tax rates are adjusted annually to reflect inflationary pressures (see Table 6).

Table 6. Carbon tax rates in Norway in the years 1991-2011 (NOK per tonne of $\left.\mathrm{CO}_{2}\right)$

\begin{tabular}{|c|c|c|c|c|c|c|c|c|}
\hline Fuel & 1991 & 1994 & 1997 & 2001 & 2005 & 2009 & 2010 & 2011 \\
\hline Petrol & 259 & 350 & 376 & 311 & 337 & 363 & 371 & 380 \\
\hline $\begin{array}{l}\text { Diesel and light heating } \\
\text { oil: } \\
\text { general rate } \\
\text { paper and pulp industry } \\
\text { and fishmeal industry } \\
\text { petroleum activities }\end{array}$ & & 160 & 164 & 182 & 198 & $\begin{array}{l}214 \\
109 \\
173\end{array}$ & $\begin{array}{l}218 \\
113 \\
177\end{array}$ & $\begin{array}{l}222 \\
116 \\
180\end{array}$ \\
\hline $\begin{array}{l}\text { Heavy fuel oil: } \\
\text { general rate } \\
\text { paper and pulp industry } \\
\text { and fishmeal industry } \\
\text { petroleum activities }\end{array}$ & 97 & & 140 & 154 & 171 & $\begin{array}{r}182 \\
92 \\
147\end{array}$ & $\begin{array}{r}185 \\
96 \\
150\end{array}$ & $\begin{array}{r}188 \\
99 \\
153\end{array}$ \\
\hline $\begin{array}{l}\text { Natural gas: } \\
\text { general rate } \\
\text { petroleum activities }\end{array}$ & 257 & & & & & $\begin{array}{l}209 \\
197 \\
\end{array}$ & $\begin{array}{l}218 \\
201 \\
\end{array}$ & $\begin{array}{l}221 \\
205 \\
\end{array}$ \\
\hline $\mathrm{Coal}^{\mathrm{a})}$ & - & & 179 & & - & - & - & - \\
\hline
\end{tabular}

a) Coal (and coke) was subject to carbon tax in Norway from 01.07.1992 to 31.12.2002.

Source: Hoerner, Bosquet (2001, p. 99), Energy policies of IEA ... (2001, p. 37), Green taxes 2011 (2011), Lindhjem et a. (2009, p. 65), Andersen et al. (2000, p. 46), Norway's fifth national... (2010), Norway's fourth national... (2005), Norway's third nationa ... (2002), Norway's second... (1997), Norway's national communication... (1994), OECD (2011, p. 126).

Table 6 shows that carbon tax rates do not fully reflect the carbon content of fuels. For example, the structure of the tax rate is based on an assumption of higher level of taxation for petrol than for diesel. From the climate change policy there is no justification for such tax rate differentiation: $\mathrm{CO}_{2}$ emissions from a litre of diesel are $12 \%$ higher than those from a litre of petrol (OECD 2011, p. 54). Another feature of the carbon tax in Norway is that fuels consumed in the mainland are subject to higher tax rates ${ }^{3}$.

\footnotetext{
${ }^{3}$ The country with the highest carbon tax rate is Sweden (the tax rate is more than 100 euro per tonne of $\mathrm{CO}_{2}$ ). In Norway the tax rate for petrol is 48,6 euro per tonne of $\mathrm{CO}_{2}$.
} 
Another observation from Table 6 is that some energy-intensive industries benefit from reduced tax rates of the carbon taxes. The tax rate for pulp, paper and the fishmeal industry is reduced by around 50\% (Andersen et al. 2000 , p. 47). The offshore oil industry also enjoyed reduced taxes, however tax rates for this sector - as announced in 2012 - were to be significantly increased (up to $420 \mathrm{NOK}$ per tonne of $\mathrm{CO}_{2}$ ). The revenues were to be deposited into a special fund for clean technologies development and public transport development. It is worth noting than in previous years there were also tax exemptions for refineries on land, air transport or the fishing fleet (Andersen et al. 2000, p. 47). Due to tax exemptions and reductions only $60 \%$ of carbon dioxide emissions in Norway was subject to tax (Norway's third national... 2002, Norway's second national... 1997, Norway's fifth national... 2010).

The introduction of a carbon tax in the early nineties was accompanied by discussions about the use of tax revenue. Representatives of environmental organizations, companies, Ministry of the Environment and the Ministry of Trade and Industry called for the earmarking of tax revenue for environmental purposes. Eventually this option was rejected. The tax is a "pure" fiscal tax: it goes into the general budget and is not earmarked for environmental investments (Kasa 1999, p. 9).

In 1996 a report of a special commission (so called Green Tax Commission) was published. The main purpose of the commission's work was to make recommendations related to an environmental tax reform which may bring about an improvement in both the environment and the economy (especially in terms of higher employment $)^{4}$. The report contained simulations of environmental and economic effects of recommended policy measures.

The Norwegian Green Tax Commission analysed the option of using carbon tax as part of an environmental tax reform. One of the conclusions that came out of the Commission's report was that in the longer run "green" tax reform may boost employment. The tax reform also may significantly affect the situation of some regions or sectors (Majocchi 2000, p. 14).

The environmental tax reform was introduced in Norway in 1999. Additional revenue resulting from the carbon tax (and the sulphur dioxide tax) was used to cut down the income tax. The reform has shifted the tax base from income to environmental depletion and pollution. The scale of this tax shift was rather limited (around 0,2\% of total tax revenue for 1999) (Hoerner, Bosquet 2001, p. 23). One can also assume that some kind of "implicit environmental tax reform" in Norway took place a few years earlier - when the introduction of a carbon tax has eliminated the need for increases in income taxes.

\footnotetext{
${ }^{4}$ It is worth noting that green tax commissions on environmental taxes have also been established in other Northern European countries.
} 
Other taxes in Norway can also play an important role in a climate policy. Such taxes include inter alia energy taxes, that is taxes levied on energy products. Taxing the energy products is less effective approach of reducing carbon emissions than carbon taxes because energy taxes provide weaker incentive for fuel substitution (Stavins 1997, p. 11; Zhang, Baranzini, 2004, p. 508).

Table 4 shows that the energy carriers in Norway are subject to multiple taxes. One of them is a general tax levied on mineral oils, kerosene and fuel oils. This tax increases the price of oil for heating purposes and gives incentives to substitute heating oil with electricity (Lindhjem et al. 2009, pp. 64-65). The rates of this tax are given in table 7.

Table 7. Tax rates of general mineral oil tax and tax on electricity consumption in Norway in the years 2005-2012

\begin{tabular}{|l|r|r|r|r|}
\hline \multicolumn{1}{|c|}{ Specification } & $\mathbf{2 0 0 5}$ & $\mathbf{2 0 0 9}$ & $\mathbf{2 0 1 1}$ & $\mathbf{2 0 1 2}$ \\
\hline \multicolumn{4}{|c|}{ General mineral oil tax (NOK per litre) } \\
\hline General rate & $\cdot$ & 0,870 & 0,983 & 0,999 \\
\hline $\begin{array}{l}\text { Reduced rate (paper and pulp, dyes and } \\
\text { pigments) }\end{array}$ & $\cdot$ & 0,12 & 0,126 & 0,126 \\
\hline \multicolumn{5}{|c|}{ Electricity tax (NOK per 1 kWh) } \\
\hline General rate & 0,0988 & 0,1085 & 0,1121 & 0,1139 \\
\hline Reduced rate (manufacturing) & 0,0045 & 0,0045 & 0,0045 & 0,0045 \\
\hline
\end{tabular}

Source: Green taxes 2011 (2011), Norway's fifth national... (2010).

The rate of electricity tax is approximately $0,11 \mathrm{NOK}$ per $1 \mathrm{kWh}$. The tax is not important from the point of view of climate change policy, since electricity in Norway is mainly produced in hydroelectric power plants.

The most popular transportation fuels are exempted from the general mineral oil tax. These fuels are subject to petrol tax and autodiesel tax (Table 8 ). It should be added that motor fuels are also subject to VAT. The tax rate is $25 \%$. 
Table 8. Transportation fuel tax rates in Norway in the years 2000-2012 (NOK per litre)

\begin{tabular}{|c|c|c|c|c|c|c|}
\hline Tax & 2000 & 2005 & 2009 & 2010 & 2011 & 2012 \\
\hline \multicolumn{7}{|c|}{ Petrol } \\
\hline Petrol tax & 4,34 & 4,03 & 4,46 & 4,54 & 4,62 & 4,73 \\
\hline $\mathrm{CO}_{2} \operatorname{tax}$ & 0,94 & 0,78 & 0,84 & 0,86 & 0,88 & 0,89 \\
\hline \multicolumn{7}{|c|}{ Diesel } \\
\hline Autodiesel tax & 3,74 & 2,92 & 3,50 & 3,56 & 3,62 & 3,73 \\
\hline $\mathrm{CO}_{2}$ tax & 0,46 & 0,52 & 0,57 & 0,58 & & 0,60 \\
\hline
\end{tabular}

Source: OECD (2011, p. 46), Fridstrøm (2012, p. 4), Green taxes 2011 (2011), Norway's fourth national... (2005).

As Table 9 illustrates, energy taxes applied in Norway increase the fuel price relative to the fuel price in European Union countries. This situation occurs despite the fact that Norway has huge energy resources. Part of the revenue from oil exports has been invested in a special fund (since 1990 - in the Government Petroleum Fund, and since 2006 - in the Government Pension Fund - Global). The fund invests in foreign securities (Czarny 2008, p. 145). As noted by T. Żylicz, this solution prevents the decline of Norwegian welfare after the exhaustion of hydrocarbons. The development in Norway is likely to be a sustainable (Żylicz 2008), at least according to a weak sustainability principle. Weak (form of) sustainability assumes that different types of capital (especially natural capital and man-made capital) are perfect substitutes (Śleszyński 2000, pp. 262-263).

Table 9. Tax rates and the price of transportation fuels in Norway, the European Union and Poland in 2010 (in euro per litre)

\begin{tabular}{|l|r|r|r|}
\hline \multicolumn{1}{|c|}{ Country } & \multicolumn{1}{c|}{ Total taxes } & $\begin{array}{c}\text { Of which ex- } \\
\text { cise duties }\end{array}$ & \multicolumn{1}{c|}{ Fuel price } \\
\hline \multicolumn{4}{|c|}{ Gasoline 95 } \\
\hline EU-27 (min-max) & $0,48-0,96$ & $0,34-0,72$ & $1,02-1,50$ \\
\hline Norway & 0,94 & 0,64 & 1,50 \\
\hline Poland & 0,58 & 0,39 & 1,07 \\
\hline \multicolumn{4}{|c|}{ Diesel } \\
\hline EU-27 (min-max) & $0,43-0,82$ & $0,27-0,63$ & $0,98-1,31$ \\
\hline Norway & 0,77 & 0,49 & 1,39 \\
\hline Poland & 0,48 & 0,30 & 1,00 \\
\hline
\end{tabular}

Source: Energy prices and taxes...2011 (2011, pp. 70-464). 
The tax which aims to reduce greenhouse gas emissions in Norway is the motor vehicle registration tax (vehicle purchase tax). The tax scheme was changed in 2007, and differentiated according to carbon dioxide emissions (Table 10). The second environmentally related element in the motor vehicle tax is the NOx component (depending on nitrogen oxide emissions per $\mathrm{km}$ ). The tax is also based on motor effect and vehicle weight.

Table 10. The rates of motor vehicle registration tax in Norway in the years 2007$2012\left(\mathrm{NOK}\right.$ per $\left.1 \mathrm{~g} \mathrm{CO}_{2} / \mathrm{km}\right)$

\begin{tabular}{|c|c|c|c|c|}
\hline Specification & 2007 & 2010 & 2011 & 2012 \\
\hline $\begin{array}{l}\text { First } 120 \text { grams (in 2007), } 115 \\
\mathrm{~g} / \mathrm{km} \text { (in 2010-2011) or } 110 \mathrm{~g} / \mathrm{km} \\
\text { (in 2012) }\end{array}$ & 40,20 & - & - & - \\
\hline Next $20 \mathrm{~g} / \mathrm{km}$ & 190,94 & 725,00 & 738,00 & 750,00 \\
\hline Next $40 \mathrm{~g} / \mathrm{km}$ & 502,47 & 731,00 & 744,00 & 756,00 \\
\hline Next $70 \mathrm{~g} / \mathrm{km}$ & - & $1.704,00$ & $1.735,00$ & $1.663,00$ \\
\hline Further emission & $1.406,90$ & $2.735,00$ & $2.784,00$ & $2.829,00$ \\
\hline $\begin{array}{l}\text { Deduction per gram } \mathrm{CO}_{2} \text { from } 115 \\
\text { to } 50 \text { gram (only for vehicles with } \\
\mathrm{CO}_{2} \text { emissions under } 120 \mathrm{~g} / \mathrm{km} \text { ) }\end{array}$ & - & 609,00 & 620,00 & 750,00 \\
\hline $\begin{array}{l}\text { Deduction per gram } \mathrm{CO}_{2} \text { below } 50 \\
\text { gram (only for vehicles with } \mathrm{CO}_{2} \\
\text { emissions under } 50 \mathrm{~g} / \mathrm{km} \text { ) }\end{array}$ & - & 609,00 & 738,00 & 850,00 \\
\hline
\end{tabular}

Source: Direct and Indirect Taxes...(2011, p. 17), Fridstrøm (2012, p. 5); Lindhjem et al. (2009, p. 77).

The purpose behind the motor registration tax is, in part, to implement the "polluter pays" principle, which in this case requires that the owners of high emitting cars pay higher taxes while environmentally friendly cars are eligible for significant tax reductions (Loma 2012).

Hydrogen powered vehicles and electric (except hybrids) are exempted from registration tax (Fridstrøm 2012, p. 6). Such vehicles are also exempted from VAT and annual tax on motor vehicles. The tax rates of the latter tax are not differentiated to reflect environmental externalities (Fridstrøm 2012, p. 7).

Policy instruments in Norway to reduce GHG emissions include not only taxes levied (directly or indirectly) on carbon dioxide emissions, but also on other gases causing greenhouse effect such as hydrofluorocarbons (HFC) and perfluorocarbons (PFC). The HFC and PFC tax is levied on the import and production of HFCs and PFCs. The aim of the tax is the reduction of 
fluorinated gas emissions and the use of alternative gases (Lindhjem et al. 2009 , p. 74). As shown in Table 11, the HFC and PFC tax rate increased by $22 \%$ in the period 2004-2012.

Table 11. Rates of tax on HFC and PFC and tax on incinerated waste in Norway in the years 2004-2012

\begin{tabular}{|c|c|c|}
\hline Year & $\begin{array}{c}\text { Tax rate (NOK per } \mathbf{C O}_{2^{-}} \\
\text {equivalent) }\end{array}$ & $\begin{array}{c}\text { Tax rate (NOK per } \\
\text { tonne of waste) }\end{array}$ \\
\hline 2004 & 184,00 &. \\
\hline 2005 & 187,27 & 40,57 \\
\hline 2006 & 190,55 & 41,28 \\
\hline 2007 & 193,98 & 59,00 \\
\hline 2008 & 199,00 & 60,53 \\
\hline 2009 & 204,99 & 62,35 \\
\hline 2011 & 212,00 &. \\
\hline 2012 & $225,00^{\text {a) }}$ &. \\
\hline
\end{tabular}

a) For example, HFC-43-10mee was levied in 2012 at 292,5 NOK per kg. The globalwarming potential for HFC-43-10mee is 1300 . The tax rates varied from 32 NOK $(4,1$ euro) to $2632,5 \mathrm{NOK}$ (336,4 euro) per $\mathrm{kg}$.

Source: Green taxes 2011 (2011), Direct and Indirect Taxes..., Norway's fifth national... (2010), Excise duty on... (2012), Lindhjem et al. (2009), pp. 73-74; Speck et al. (2006, p. 186), Norway's fourth national... (2005).

The group of taxes which promote reduction of greenhouse gas emissions in Norway also include the tax on waste destined for incineration. The Table 11 shows that in 2009 the rate of $\mathrm{CO}_{2}$ tax on incinerated waste was around 62 NOK per tonne of waste.

It should be noted that there are also other non-fiscal instruments of climate policy in Norway. One of them is the European emission trading scheme. Norway joined the scheme in $2008^{5}$. Because the emission trading scheme has covered petroleum industry (petroleum activities on the continental shelf) the carbon tax for this sector was lowered. The reason for this was the need to maintain the full incentive to reduce greenhouse gas emissions and to avoid excessive costs for the industry (Lindhjem et al. 2009, p. 66). Another important tool for climate policy in Norway are the voluntary agreements between industry and public authorities. The agreements may concern the reduction of sulphur hexafluoride emissions.

\footnotetext{
${ }^{5}$ There was a domestic emission trading scheme in Norway in the years 2005-2007.
} 
The review of Norwegian experience with environmental taxes provide some conclusions and recommendations for the Polish climate policy.

The first important issue is introducing a carbon tax on energy carriers. Currently, carbon dioxide emissions in Poland are subject to environmental charge. In 2012 the charge rate was only $0,27 \mathrm{zf}(0,06$ euro) per tonne of $\mathrm{CO}_{2}$. In practice, the charge is levied only on some stationary sources. Transport fuels are subject to excise duty which rates are much lower than rates of taxes paid in Norway (see Table 9). A carbon tax on fuels could be revenue neutral: the tax revenue could be returned to the economy through reductions in other taxes or social security contributions.

Another important issue could be the "greening" of the vehicle taxation system in Poland. The excise duty on passenger cars could depend on carbon dioxide emissions per kilometre. Currently, the excise duty on passenger cars in Poland is based on engine capacity.

The emissions of hydrofluorocarbons and perfluorocarbons are subject to pollution charge. In $2012 \mathrm{r}$. the rate of the charge was $27,66 \mathrm{zl}$ (6,3 euro) per tonne of $\mathrm{HFC}$ and $\mathrm{PFC}^{6}$.

\section{The effects of environmental taxes}

As early as in the first half of the nineties there was a research conducted on the effectiveness and efficiency of the carbon tax in Norway. Results of these studies have indicated that the carbon is not cost-efficient due to significant differences in the tax rates applied to various sectors and various fuels (Andersen et al. 2000, p. 47).

In more recent years, a number of studies have examined the impact of various measures to reduce greenhouse gas emissions in Norway. These estimates indicate that if such measures as environmental taxes, emission trading scheme, requirements for landfills or agreements between industry and public authorities were not implemented, greenhouse gas emission in 2010 would be 10,8 million tonnes higher (table 13). The main contribution to greenhouse gas emission reduction comes from carbon taxes levied on companies operating on the Norwegian continental shelf.

\footnotetext{
${ }^{6}$ Obwieszczenie Ministra Środowiska z dnia 26 września 2011 r. w sprawie wysokości stawek opłat za korzystanie ze środowiska na rok 2012 (M.P. 2011 r., 94, 958).
} 
Table 13. Effects of selected policy measures implemented in Norway to reduce greenhouse gas emissions (million tonnes $\mathrm{CO}_{2}$ equivalents)

\begin{tabular}{|l|r|r|r|r|r|r|}
\hline \multicolumn{1}{|c|}{ Specification } & \multicolumn{1}{|c|}{$\mathbf{1 9 9 5}$} & $\mathbf{2 0 0 0}$ & $\mathbf{2 0 0 5}$ & $\mathbf{2 0 0 7}$ & $\mathbf{2 0 1 0}$ & \multicolumn{1}{c|}{$\mathbf{2 0 2 0}$} \\
\hline Total effect, of which: & $2,5-3,8$ & $6,8-$ & $8,9-$ & $9,6-$ & $10,8-$ & $13,3-$ \\
& & 9,0 & 11,8 & 12,5 & 14,2 & 16,7 \\
\hline $\mathrm{CO}_{2}$ tax offshore & 0,6 & 3,0 & 3,0 & 4,5 & $5,2^{\text {a) }}$ & $6,9^{\text {a) }}$ \\
\hline $\mathrm{CO}_{2}$ tax onshore & - & 0,8 & 0,8 & 0,85 & 0,85 & 0,85 \\
\hline $\mathrm{HFC}$ tax & - & - & 0,3 & 0,5 & 0,5 & 0,5 \\
\hline $\mathrm{CO}_{2}$ dependent tax & - & - & - & 0,04 & 0,1 & 0,4 \\
for new passenger & & & & & & \\
\hline $\begin{array}{l}\text { Voluntary reductions } \\
\text { with aluminium in- } \\
\text { dustry }\end{array}$ & $0-1,3$ & $0,5-$ & $1,6-$ & $1,6-$ & $1,5-$ & $1,8-$ \\
\hline
\end{tabular}

a) The effect is the sum of the $\mathrm{CO}_{2}$ tax and the price of the $\mathrm{CO}_{2}$ allowances (in 2008 the $\mathrm{CO}_{2}$ tax rate for petroleum sector was reduced, since petroleum sector was included in the EU emission trading scheme).

Source: Norway's fifth national... (2010).

Passenger car taxation has also been important instrument for reducing emissions in Norway. In the years 2006-2011 the average $\mathrm{CO}_{2}$ emissions of new cars dropped by $24 \%$, and in $2006-2012$ - by $27 \%$. For comparison, in the period from 2006 to 2011 the average $\mathrm{CO}_{2}$ emissions in the 27 European Union member states declined by $16 \%$. Car buyers in Norway have quickly responded to new fiscal incentives. For example, in the years 2009-2010 the purchases of cars emitting less than $120 \mathrm{~g} / \mathrm{km}$ increased by more than $100 \%$ (from $14,7 \%$ to $30,1 \%$ ) (Duer et al. 2011, p. 57).

\section{Conclusions}

Norwegian experience in climate change policy is interesting for at least several reasons. The most important of them are: ambitious targets for reducing greenhouse gas emissions, high fuel taxation, two parallel economic approaches to greenhouse gas reduction (carbon tax and the emission trading scheme) and distinct environmental effects. The climate change policy relies on interesting instruments such as $\mathrm{CO}_{2}$ tax on incinerated waste.

Tax rates in Norway are adjusted to price level increases. This keeps the tax burden from declining in real terms and maintains the incentive to reduce emissions. However, differences in tax rates on energy for different fuels (especially petrol and diesel) and for different sectors of the economy have a negative impact on the effectiveness of environmental policy. As mentioned, the condition for cost-effectiveness of environmental policy is equal- 
ization of marginal costs of emission reductions across all economic actors. Therefore, the price of emissions (the tax rate) should be the same for all firms and sectors.

The Norwegian experience can be important for the Polish environmental policy. The factors of particular interest are the experience with carbon tax, green tax reforms and vehicle taxation scheme based on $\mathrm{CO}_{2}$ emissions. Of course, the introduction of such measures in Poland should take into account national circumstances (e.g. related to the structure of the tax system).

\section{References}

Andersen M., Dengsøe N., Pedersen A. (2000), An evaluation of the impact of green taxes in the Nordic countries, TemaNord, Copenhagen, https://pure.au.dk/portal/files/56716516/NMR2001_566.pdf(28.02.2013).

Budget 2011, Ministry of Finance, http://www.regjeringen.no/upload/FIN/Info/ Budget_2011.pdf(01.01.2013).

Czaja S., Becla A. (2002), Ekologiczne podstawy procesów gospodarowania, Wydawnictwo Akademii Ekonomicznej we Wrocławiu, Wrocław.

Czarny R. (2008), Państwa regionu nordyckiego wobec problemu bezpieczeństwa energetycznego [in:] Cziomer E. (ed.), Międzynarodowe bezpieczeństwo energetyczne w XXI wieku, Krakowskie Towarzystwo Edukacyjne, Kraków.

Direct and Indirect Taxes - Main Features of the 2008 Proposal, $\mathrm{http} / /$ www.regjeringen.no/en/dep/fin/Selected-topics/the-national-budget/Directand-Indirect-Taxes---Main-Feature.html?id=485144 (26.02.2013).

Duer H., Rosenhagen C., Ritnagel P. (2011), A comparative analysis of taxes and $\mathrm{CO}_{2}$ emissions from passenger cars in the Nordic countries, TemaNord, Copenhagen, http://www.norden.org/en/publications/publikationer/2011-523/at_down load/publicationfile (28.02.2013).

Emissions of greenhouse gases, 1990-2011 (2013), final figures, Statistics Norway, http://www.ssb.no/en/natur-og-miljo/statistikker/klimagassn (25.12.2013).

Energy policies of IEA countries: Norway 2001 (2001), OECD, Paris.

Energy prices and taxes. Quarterly statistics. Fourth quarter 2011 (2011), Paris, OECD/IEA, Paris.

Excise duty on hydrofluoro-carbons (HFCs) and perfluoro-carbons (PFCs) (2012), Directorate of Customs and Excise, Oslo. http://www.toll.no/upload /aarsrundskriv/Engelske/1/HFC-PFC.pdf (25.12.2013).

Fridstrøm L. (2012), Greenhouse gas abatement in the Norwegian transport sector, Institute of Transport Economics, Norwegian Centre for Transport Research, Oslo, http://www.sou.gov.se/fossilfri/pdf/Underlagsrapport\%202\%20-\%20No rge.pdf (02.03.2013).

Green taxes 2011 (2011), http://www.regjeringen.no/nb/dep/fin/tema/skatter _og_avgifter/green-taxes-2011.html?id=609076 (06.01.2013). 
Guide to environment statistics (2012), Statistics Norway, http://www.ssb.no/english/subjects/01/milfakt_en/2012/miljofakta_2012_en.pdf (01.01.2013).

Hass J., Sørensen K., Erlandsen K., Smith T. (2002), Norwegian economic and environment accounts, Project Report 2002, Statistics Norway, Oslo., http://www.ssb.no/a/english/publikasjoner/pdf/doc_200509_en/doc_200509_en. $\operatorname{pdf}(02.03 .2013)$.

Hoerner, B. Bosquet (2001), Environmental tax reform: The European experience, Center For A Sustainable Economy, Washington, http://rprogress.org /publications/2001/eurosurvey_2001.pdf (28.02.2013).

Kasa S. (1999), Social and political barriers to green tax reform. The case of $\mathrm{CO}_{2-}$ taxes in Norway, Center for International Climate and Environmental Research, Oslo, http://www.cicero.uio.no/media/57.pdf (02.03.2013).

Lindhjem H., Skjelvik J., Eriksson A., Fitch T., Hansen L. (2009), The use of economic instruments in Nordic environmental policy 2006-2009, Nordic Council of Ministers, Copenhagen. http://www.norden.org/en/publications/publikationer/ 2009-578/at_download/publicationfile (25.01.2013).

Loma U., Norway's "green" vehicle tax breaks declared a success (2012), http://www.tax-news.com/news/Norways_Green_Vehicle_Tax_Breaks_Declared A_Success__57998.html (29.10.2012).

Majocchi A. (2000), Greening tax mixes in OECD Countries: a preliminary assessment, OECD, Paris., http://search.oecd.org/officialdocuments/displaydocu mentpdf $/$ ?doclanguage $=$ en $\&$ cote $=$ com/env/epoc/daffe $/ \mathrm{cfa}(99) 112 /$ final (23.10.2011).

Norway's fifth national communication under the Framework Convention on Climate Change (2010), Norwegian Ministry of the Environment., http://unfccc.int/resource/docs/natc/nor_nc5.pdf (23.02.2013).

Norway's fourth national communication under the Framework Convention on Climate Change (2005), Norwegian Ministry of the Environment., http://unfccc.int/resource/docs/natc/nornc4.pdf (23.02.2013).

Norway's national communication under the Framework Convention on Climate Change (1994), http://unfccc.int/cop3/fccc/natcom/natc/nornc1.pdf, (23.02.2013).

Norway's second national communication under the Framework Convention on Climate Change (1997), Norwegian Ministry of the Environment., http://unfccc.int/resource/docs/natc/nornc2.pdf (23.02.2013).

Norway's third national communication under the Framework Convention on Climate Change (2002), Norwegian Ministry of the Environment., http://unfccc.int/resource/docs/natc/nornc3.pdf(23.02.2013).

Obwieszczenie Ministra Środowiska z dnia 26 września 2011 r. w sprawie wysokości stawek opłat za korzystanie ze środowiska na rok 2012 (M.P. 2011 r., 94, 958).

OECD economic surveys. Norway (2012), OECD, Paris.

OECD Environmental Performance Reviews. Norway (2011), OECD, Paris. 
Samojlik B. (2006), System podatkowy - kierunki ewolucji [in:] Samojlik B. (ed.), Kierunki zmian $w$ sektorze finansów publicznych $w$ Polsce po wejściu do Unii Europejskiej, AGH, Warszawa.

Śleszyński J. (2000), Ekonomiczne problemy ochrony środowiska, Aries, Warszawa.

Speck S., Andersen M., Nielsen H., Ryelund A., Smith C. (2006), The use of economic instruments in Nordic and Baltic environmental policy 2001-2005, Nordic Council of Ministers, Copenhagen, http://www.norden.org/en/publicat ions/publikationer/2006-525/at_download/publicationfile (20.02.2013).

Statistical yearbook of Norway 2010 (2010), Statistics Norway, Oslo., https://www.ssb.no/a/en/histstat/aarbok/2010_en.pdf (21.02.2013).

Stavins, R. (1997), Policy instruments for climate change: how can national governments address a global problem?, Resources for the Future, Washington.

Taxation of petroleum activities (2007), Ministry of Finance, http://www.regjeringen.no/en/dep/fin/Selected-topics/taxes-and-duties/bedrif tsbeskatning/Taxation-of-petroleum-activities.html?id=417318 (15.10.2010).

Taxation trends in the European Union. 2010 edition. Main results (2010), Eurostat, Luxembourg, http://epp.eurostat.ec.europa.eu/cache/ITY_OFFPUB/KS-DU-10001/EN/KS-DU-10-001-EN.PDF (24.02.2013).

Taxation trends in the European Union. 2012 edition (2012), Eurostat, Luxembourg, http://epp.eurostat.ec.europa.eu/cache/ITY_OFFPUB/KS-DU-12-001/EN/KSDU-12-001-EN.PDF (24.02.2013).

The National Budget 2012, The Royal Ministry of Finance, http://www.statsbudsjettet.no/upload/Statsbudsjett_2012/dokumenter/pdf/nb_su mmary.pdf (20.02.2013).

Zhang, Z., Baranzini, A. (2004). What Do We Know about Carbon Taxes? An Inquiry into Their Impacts on Competitiveness And Distribution of Income, "Energy Policy" 32, http://dx.doi.org/10.1016/S0301-4215(03)00152-6.

Żylicz T. (2008), „Staba” trwatość rozwoju, „Aura”, nr 7. 